\title{
Study of Autumn-Winter Weeds in Portugal and its Ecological PREFERENCES ${ }^{1}$
}

\author{
Estudo das Infestantes de Outono-Inverno em Portugal e suas Preferências Ecológicas
}

RAMÔA, S. ${ }^{2}$, OLIVEIRA e SILVA, P. ${ }^{2}$, VASCONCELOS, T. ${ }^{3}$, FORTES, P. ${ }^{3}$, and PORTUGAL, J. ${ }^{2}$

\begin{abstract}
The conclusion of the dam project located in Alqueva, in Southern Portugal, has resulted in a significant increase of new irrigated areas, since 2006. This has meant that, in recent years, there have been progressive flora changes in farming systems traditionally implemented in the Alentejo region. The present work has analyzed the weed flora in an early stage of these changes, and the impact of environmental factors on the distribution of natural vegetation under Mediterranean climate conditions in the influence area of Alqueva. In 2007, 105 floristic surveys were carried out in autumn-winter crop plots or other soil use, and 264 species were identified. Families with higher expression were: Asteraceae, Poaceae, and Fabaceae. Only three species have been identified in more than half of farms, Avena sterilis, Phalaris minor and Lolium rigidum and they were part of the 15 species that revealed high and very high infestation degrees. Soil texture and extractable phosphorus have been determined as active ecological factors, according to the method of ecological profiles and Mutual Information. Therefore, these factores were those with the greatest influence on the species distribution. L. rigidum distribution showed to be associated with medium soil texture and A. sterilis distribution also showed to be associated with medium and fine soil texture soils, without showing ecological preference by extractable phosphorus. The distribution of $P$. minor was not related to the soil texture but showed preference for soils with medium phosphorus content.
\end{abstract}

Keywords: spontaneous flora, Mediterranean climate, ecological profiles, active factors, texture, extractable phosphorus.

RESUMO - A concretização do projeto da barragem do Alqueva, no sul de Portugal, resultou, desde 2006, em aumento importante de novas áreas irrigadas. Esse fato fez com que, nos últimos anos, ocorressem alterações progressivas da flora nos sistemas agrícolas da região do Alentejo. O presente trabalho analisou a vegetação espontânea, na fase inicial das alterações nos sistemas culturais, e o impacto dos fatores ambientais sobre a sua distribuição, em condições de clima mediterrâneo, na zona de influência do Alqueva. Esses estudos são importantes para delinear estratégias controle das infestantes nas culturas. Em 2007, foram realizados 105 levantamentos floristicos, em parcelas com culturas de outono-inverno ou outros modos de uso do solo, nas quais se identificaram 264 espécies. As famílias com maior expressão foram Asteraceae, Poaceae e Fabaceae. Somente três espécies foram identificadas em mais de metade das explorações: Avena sterilis, Lolium rigidum e Phalaris minor, as quais se encontram entre as 15 espécies que revelaram grau de infestação alto e muito alto. A textura do solo e o fósforo extraivel foram determinados como fatores ecológicos ativos, segundo método dos perfis ecológicos e Informação Mútua. Assim, estes foram os factores com maior influência na distribuição das espécies. A distribuição de $\mathbf{L}$. rigidum mostrou estar associada a solos de textura mediana, e de A. sterilis, também a solos de textura mediana e fina, não apresentando preferência ecológica pelo fósforo extraivel. A distribuição de $\boldsymbol{P}$. minor não mostrou relação com a textura do solo, mas revelou preferência por solos com teores médios de fósforo.

Palavras-chave: vegetação espontânea, clima mediterrâneo, perfis ecológicos, fatores ativos, textura, fósforo extraível.

1 Recebido para publicação em 23.3.2015 e aprovado em 24.3.2015.

2 Instituto Politécnico de Beja, Beja, Portugal, <sramoa@ipbeja.pt >; ${ }^{3}$ Instituto Superior de Agronomia, Tapada da Ajuda, Lisboa, Portugal. 


\section{INTRODUCTION}

Alentejo, a territory located in the SouthCentral part of Portugal, is characterized by a Mediterranean climate and presents, as the main constraint to agricultural activity, the interannual and annual irregular regime of rainfall, affecting the yielding structure of the region. For this reason, for decades, this region depended on the arable crops of dryland farming and extensive farming exploitation and was considered at the time as the "breadbasket of Portugal". With the construction of the Alqueva dam, located in the Alentejo region, the landscape of the Alentejo agriculture has changed; this is the largest irrigation project carried out in Portugal and considered the largest fresh water reserve in Europe. It is anticipated that by $2015,120,000$ hectares will be equipped with structures for irrigation. From 2006 to $2013,60 \%$ of this area was irrigated and had different crops, predominantly olive trees. Today, other crops are gaining importance, such as maize, citrus, pomegranate, dried fruit, melon, tomato, onion, garlic and poppy, diversifying the crop systems.

Among other things, the introduction of new crop practices and the intensification of yield factors lead to a new balance in the floristic composition and diversity (Fried et al., 2008; Sans et al., 2013). Another important aspect has to do with the fact that the intensification of agricultural systems leads to a loss of plant biodiversity (Storkey \& Westbury, 2007; Stoate et al., 2009; José-Maria et al., 2010; Sans et al., 2013), which threatens the sustainability of the services provided by a current and modern agriculture. Also, the effect of climate change on organisms and on their geographical distribution (Walther et al., 2002) may influence this dynamic. Thus, the detailed knowledge of natural vegetation is particularly important as regards the definition and, later, implementation of an integrated control of weeds, focused on the sustainability of the agricultural systems, compatible with the protection of natural resources and biodiversity of agroecosystems (Fried et al., 2008). Knowledge of the floristic composition of natural vegetation and ecological factors involved in its diversity and variability is one of the key steps for the development of sustainable control models (Johnson \& Kent, 2002; Karar et al., 2005; Monteiro et al., 2012).

The objective of this work was to study the spontaneous vegetation in agricultural systems in Alentejo in the beginning of these changes, resulting from the implementation of irrigation, seeking to correlate it with environmental factors in order to establish the ecological preferences of the most important autumn-winter species identified in 2007. It is expected that this study continue, repeating the surveys in the same locations in the year 2017, with the Alqueva irrigation project up and running.

\section{MATERIALS AND METHODS}

In 2007,105 floristic surveys were performed on wheat, oats and barley, and in areas with olive trees, pine trees, fallow and pastures, recently implemented and covered by the zone of influence of Alqueva. The sites were referenced with GPS and subsequently with Quantum GIS software. Afterwards, its location was established on the Official Administrative Map of Portugal.

The surveys were conducted in months April and May (spring), at which time it is possible to identify virtually all emerged flora. The method used was "back to the field," used in studies of natural vegetation in agroecosystems (Vasconcelos et al., 1999a,b; Mesli et al., 2008; Fried et al., 2008). This method consists in choosing, for a given crop, a location that is geographically homogeneous and subsequently identify and record the species and estimate their abundance. For all plants, a recording of presence and absence was obtained and the Latin name was associated, as well as the corresponding EPPT (European and Mediterranean Plant Protection Theasaurus, previously Bayer code) code. Estimating the abundance of each species present was defined according to the scale also used by Fried et al. (2012) and Monteiro et al. (2012), considering the following abundance coefficients: 1 - abundance estimated as lower than an individual per $\mathrm{m}^{2} ; 2$ - estimated abundance of 1-2 individuals per $\mathrm{m}^{2} ; 3$ estimated abundance of 3-20 individuals per $\mathrm{m}^{2} ; 4$ - estimated abundance of 
21-50 individuals per $\mathrm{m}^{2}$; and 5 - estimated abundance higher than 50 individuals per $\mathrm{m}^{2}$.

Soil samples were collected at $25 \mathrm{~cm}$ depth in places where flora surveys were conducted, for posterior analysis. Taking into account the ecological factors studied in similar works in different habitats and different objectives (Hidalgo et al., 1990; Saavedra et al., 1990; Vasconcelos et al., 1999a,b, Zas \& Alonso, 2002; Dezzeo et al., 2004; Hyvönen et al., 2005; Devineau \& Fournier, 2007; Fariña et al., 2008), the following environmental variables were analyzed: extractable potassium, extractable phosphorus, $\mathrm{pH}\left(\mathrm{H}_{2} \mathrm{O}\right)$, texture, type of soil, precipitation and type of crop. The soil texture was determined by granulometry analysis (grain size analysis), and the texture designation was obtained from the diagram by Gomes \& Silva (1962); pH was determined by potentiometry (METROHM 632 pH-Meter); phosphorus and extractable potassium contents were assessed according to the method of Egner-Riehm (Almeida \& Balbino, 1960), and the phosphorus content was determined by molecular absorption spectrophotometry at $650 \mathrm{~nm}$ (SHIMADZU uv Visible Spectrophotometer 1603), and the potassium content by means of a flame photometer (SHERWOOD Flame photometer 410). Classification has been established for texture and phosphorus and potassium content, according to Vasconcelos et al. (1999 a, b).

With the Quantum GIS software, the points were superimposed, referenced with the GPS on the soils map of the Atlas do Ambiente (Environmental Atlas) (2011), which is in accordance with the World Reference Base for Soil Resources classification. Thus, it was possible to identify the different types of soil in each inventoried plot and establish the soil classification. With regard to rainfall, the classification was established from the values of the cumulative average rainfall from October to May for each site where the floristic surveys were carried out. In the flora surveys, the number of species present was determined, with which were obtained the values of absolute frequency $(\mathrm{AF})$ and relative frequency (RF). From the estimated abundance coefficients in the field, the average abundance (AM) was calculated according to equation 1 , where $n_{i}$ is the number of surveys in which a given species shows an abundance coefficient of $i$.

$A M=\frac{n_{1} \times 0.5+n_{2} \times 1.5+n_{3} \times 11.5+n_{4} \times 35.5+n_{5} \times 75.5}{n_{1}+n_{2}+n_{3}+n_{4}+n_{5}} \quad$ (eq. 1$)$

The degree of infestation of the species due to the relative frequency and average abundance was determined, according to Monteiro et al. (2012), according to the Table 1.

Table 1 - Degree of infestation of the species according to their relative frequency and average abundance

\begin{tabular}{|c|c|c|c|}
\hline \multirow{2}{*}{$\begin{array}{l}\text { Coefficient of } \\
\text { abundance }\end{array}$} & \multicolumn{3}{|c|}{ Relative frequency (\%) } \\
\hline & $<25$ & $25-50$ & $>50$ \\
\hline 1 & 0 & + & \\
\hline 2 & + & \multirow[b]{2}{*}{++} & \\
\hline 3 & & & \\
\hline 4 & & \multirow[b]{2}{*}{+++} & \\
\hline 5 & & & ++++ \\
\hline
\end{tabular}

0 - very low; + - low; ++ - average; +++ - high; ++++ - very high.

The ecological profile set, absolute frequency, relative frequency and corrected frequencies were calculated according to Vasconcelos et al. (1999a,b), and Fariña et al. (2008). Mutual Information $[\operatorname{IM}(\mathrm{L}, \mathrm{E})]$ of the species for the ecological factors analyzed and the respective sampling quality [Q (L)] were calculated according to equations 2 and 3.

$$
\begin{aligned}
& I M(L, E)=\sum_{1}^{N K} \frac{U(K)}{N R} \log _{2}\left(\frac{U(K)}{R(K)} \times \frac{N R}{U(E)}\right)+\sum_{1}^{N K} \frac{V(K)}{N R} \times \log _{2}\left(\frac{V(K)}{R(K)} \times \frac{N R}{V(E)}\right) \\
& Q(L)=\frac{\hat{H}(L)}{\hat{H}(L)_{\max }}
\end{aligned}
$$

where $N K$ - number of $L$ factor classification; $U(K)$ - number of surveys of $K$ classification with $E$ species present; $V(K)$ - number of surveys of $K$ classification with $E$ species absent; $N R$ - total number of surveys; $R(K)$ number of $K$ classification surveys; $U(E)$ - total number of surveys with $E$ species present; $V(E)$ - total number of surveys with $E$ species absent; $\hat{H}(L)_{\max }$ - maximum entropy factor; $\hat{H}(L)$ - entropy factor. 
The factors that play an important role in the distribution of the species are called active factors and are those which simultaneously show values of $\operatorname{IM}(\mathrm{L}, \mathrm{E}) \geq 0.05$ bits and a good sample quality $[Q(L) \geq 0.9]$ (Vasconcelos et al., 1999a,b).

\section{RESULTS AND DISCUSSION}

Were identified 264 species, distributed among 43 families. Comparing the total number of species identified with other studies conducted in the Mediterranean region, it is found that the floristic diversity is high. One example is in the 175 species identified by Cirujeda et al. (2011) in 138 samples collected in Aragão (Spain) and 278 species in 86 inventories done in Greece (Damanakis, 1983). These numbers are much higher compared to those found in northern and central Europe, agreeing with Holzner \& Immonen (1982), indicating that floristic diversity is higher in the Mediterranean areas. Thus, in central and southern England 46 species were recorded in 100 plots (Sutcliffe \& Kay, 2000); in northern England, 87 species in 1,021 samples (Chancellor \& Froud-William, 1984); and in Finland, 160 species in 690 plots (Salonen et al., 2001). On the other hand, Calha et al. (2014a) have identified 43 weed species in maize, accounting for 21 families in Golegã, Ribatejo (Portugal).

Families with greater representation were Asteraceae (19\%), followed by Poaceae (17\%) and Fabaceae (14\%), which represented 50\% of the species total. These families also had a higher expression in studies undertaken in the central region of Portugal (Beira Alta) in vineyards (Monteiro et al., 2012); also in central Portugal (Golegã) families Poaceae e Asteraceae stood out in maize (Calha et al., 2014a).

Only three species have been identified in more than half of the surveys conducted: Avena sterilis, Lolium rigidum and Phalaris minor. This value is very close to the number of the most frequent species identified in the area of Aragão (Spain) by Cirujeda et al. (2011), and $L$. rigidum and $A$. sterilis are coincident.

The degree of infestation of the species identified indicates that L. rigidum (LOLRI) was the only species that showed a very high degree of infestation. Fourteen species showed a high degree of infestation, among which is A. sterilis (AVEST). Phalaris minor (PHAMI) showed an average degree of infestation.

Lolium rigidum was found in various other places as a very frequent and abundant species, such as in cereals in Spain (Recasens et al., 1996; Cirujeda et al., 2011). In turn, Borger et al. (2012) record it, too, as very frequent and abundant in Australia. In Portugal, $L$. rigidum was identified with a high degree of infestation in vineyards in the BeiraAlta region (Monteiro et al., 2012). Also, very recently, there have been reports of resistance to pinoxaden herbicide in the Alentejo region (Calha et al., 2014b). According to Cirujeda et al. (2011), A. sterilis is considered one of the worst weeds in the wheat crop in the region of Aragon (Spain), is difficult to control and exhibits resistance to herbicides. Armengot et al. (2011), in the Mediterranean region, indicate that species such as L. rigidum are associated with the intensification of agricultural practices. According to Sans et al. (2013), the increase in pressure of the herbicides has led to the emergence of populations resistant to herbicides, with reduction of dicotyledons and increase of monocotyledons belonging to the Poaceae family, such as $L$. rigidum, A. sterilis and $P$. minor. Another important finding is the small number of problematic species regarding the global floristic assembly, which agrees with what was found by Borger et al. (2012) in Australia. This fact may result from the repetition of a set of cultural practices in controlling weeds, which could lead to a selection of species (Sans et al., 2013).

With regard to ecological preferences, texture and phosphorus are considered active factors in species distribution.

The $\mathrm{pH}$ factors, soil type, crops and precipitation showed sampling quality values lower than 0.9, despite the mutual information values $[\operatorname{IM}(\mathrm{L}, \mathrm{E})]$ having been $\geq$ at 0.05 . These results should be interpreted with some caution. The extractable potassium, despite showing some good quality sample, expressed low relationship with the species (mutual 
information values less than 0.05). Tables 2 and 3 show the ecological preferences of the species with relative frequency $\geq 25 \%$ and for all the others that have shown average, high and very high degrees of infestation, potentially problematic for crops.

Species Echium plantagineum, Carlina racemosa, Spergularia purpurea, Raphanus raphanistrum, Agrostis pourretii, Galactites tomentosa and Bromus hordeaceus have expressed preferences for thick and medium thick textured soils and species Chamaemelum mixtum, Trifolium campestre and Hordeum murinum have expressed preferences for thick textured soils (Table 2). With regard to medium thick, medium fine and fine textured soils, the following species were identified: A. sterilis, Plantago lagopus, Scolymus maculatus and Sonchus oleraceus; for medium fine and fine textured soils, Convolvulus arvensis; for medium thick and medium fine textured soils, Lactuca serriola,
L. rigidum and Rumex pulcher, and for thick, medium fine and fine textured soils, Anagallis arvensis. Cynodon dactylon preferred thick and fine textured soils, and Diplotaxis catolica, thick and medium fine textured soils. It should be emphasized that $P$. minor is not in this table, since for the factor in question it showed values of $\operatorname{IM}(\mathrm{L}, \mathrm{E})<0.05$.

Species that expressed a preference for soils with low phosphorus content were: T. campestre, S. purpurea, A. pourretii, Leontondon taraxacoides, Trifolium glomeratum, Vulpia geniculata, R. raphanistrum, G. tomentosa, B. hordeaceus, Vulpia ciliata, C. mixtum, E. plantagineum and R. pulcher, in soils with phosphorus average levels, were identified: Bromus diandrus, H. murinum, Crepis vesicaria, Medicago polymorpha, Andryala integrifolia, $A$. arvensis, $P$. minor and Phalaris coerulescens; and in soils with a high phosphorus content: Sonchus oleraceus, Scolymus maculatus and Foeniculum vulgare.

Table 2 - Ecological preferences of weed species in wheat, oats and barley crops, in areas with olive trees, pine trees, fallow and pasture covered by the zone of influence of Alqueva, Portugal, for the texture factor

\begin{tabular}{|c|c|c|c|c|c|c|}
\hline Groups & Species & EPPO Code & 1 & 2 & 3 & 4 \\
\hline \multirow{7}{*}{1} & Echium plantagineum & EHIPL & + & + & - & - \\
\hline & Spergularia purpurea & SPBPU & + & + & - & \\
\hline & Raphanus raphanistrum & RAPRC & + & + & - & \\
\hline & Agrostis pourretii & AGSSA & + & + & - & \\
\hline & Galactites tomentosa & GCTTO & + & + & - & \\
\hline & Carlina racemosa & CIIRA & + & + & - & \\
\hline & Bromus hordeaceus & BROMO & + & + & - & \\
\hline \multirow{3}{*}{2} & Chamaemelum mixtum & ANTMI & + & - & - & - \\
\hline & Trifolium campestre & TRFCA & + & - & & \\
\hline & Hordeum murinum & HORLE & + & - & - & \\
\hline \multirow{4}{*}{3} & Avena sterilis & AVEST & - & + & + & + \\
\hline & Plantago lagopus & PLALG & - & + & + & + \\
\hline & Scolymus maculatus & SCYMA & - & + & + & + \\
\hline & Sonchus oleraceus & SONOL & - & + & + & + \\
\hline 4 & Convolvulus arvensis & CONAR & - & - & + & + \\
\hline \multirow{3}{*}{5} & Lactuca serriola & LACSE & - & + & + & \\
\hline & Lolium rigidum & LOLRI & - & + & + & - \\
\hline & Rumex pulcher & RUMPU & - & + & + & - \\
\hline 6 & Anagallis arvensis & ANGAR & + & - & + & + \\
\hline 7 & Cynodon dactylon & CYNDA & + & - & - & + \\
\hline 8 & Diplotaxis catolica & DIPCA & + & & + & \\
\hline
\end{tabular}

Texture classification: (1) thick, (2) medium thick, (3) medium fine, (4) fine. Index of the corrected frequencies: >100 (+) positive relationship; <100 (-) negative relationship; = $100(0)$, there is no relationship. 
Lolioum rigidum and $A$. sterilis showed values of $\operatorname{IM}(\mathrm{L}, \mathrm{E})<0.05$, which is why they have not shown an ecological preference for phosphorus (Table 3).

All species have shown large ecological amplitudes, ranging from low to high soil phosphorus content. Exception was found for S. purpurea, L. taraxacoides, A. pourretii, $V$. geniculata, R. raphanistrum, G. tomentosa, R. pulcher, B. diandrus, H. murinum and $M$. polymorpha for very high contents; $T$. campestre and T. glomeratum, for high and very high contents; $V$. ciliata, for very low, high and very high contents; and S. maculatus, for very low phosphorus contents.

In light of the results obtained, it can be stated that: the main families identified were Asteraceae, Poaceae and Fabaceae; the number of taxa inventoried in Mediterranean climate conditions was very high, but only a relatively small group of them (15) showed very high and high degrees of infestation and it is possible to consider this as a potential cause of future economic losses; highlights were three species of the Poaceae family: $L$. rigidum, $A$. sterilis and $P$. minor. Soil texture and extractable phosphorus were the ecological factors with greater influence in the distribution of the species. The ecological response of $L$. rigidum has shown to be associated with medium textured soils, and of $A$. sterilis also to medium and fine textures, showing no ecological preference for extractable phosphorus. The distribution of $P$. minor was not related to soil texture, but revealed a preference for soils with average phosphorus levels.

Table 3 - Ecological preferences of weed species in wheat, oats and barley crops, in areas with olive trees, pine trees, fallow and pasture covered by the zone of influence of Alqueva, Portugal, for the phosphorus factor

\begin{tabular}{|c|c|c|c|c|c|c|c|c|}
\hline Groups & Species & EPPO Code & 1 & 2 & 3 & 4 & 5 & Barycenters \\
\hline \multirow{13}{*}{1} & Trifolium campestre & TRFCA & $\mathrm{x}$ & & & & & 1.7 \\
\hline & Spergularia purpurea & SPBPU & $\mathrm{x}$ & & & & & 1.8 \\
\hline & Agrostis pourretii & AGSSA & & $\mathrm{x}$ & & & & 2.0 \\
\hline & Leontondon taraxacoides & LEBNT & & $\mathrm{x}$ & & & & 2.2 \\
\hline & Trifolium glomeratum & TRFGL & & $\mathrm{x}$ & & & & 2.2 \\
\hline & Vulpia geniculata & VLPGE & & $\mathrm{x}$ & & & & 2.2 \\
\hline & Raphanus raphanistrum & RAPRC & & $\mathrm{x}$ & & & & 2.2 \\
\hline & Galactites tomentosa & GCTTO & & $\mathrm{x}$ & & & & 2.2 \\
\hline & Bromums hordeaceus & BROMO & & $\mathrm{x}$ & & & & 2.3 \\
\hline & Vulpia ciliata & VLPCI & & $\mathrm{x}$ & & & & 2.3 \\
\hline & Chamaemelum mixtum & ANTMI & & $\mathrm{x}$ & & & & 2.4 \\
\hline & Echium plantagineum & EHIPL & & $\mathrm{x}$ & & & & 2.4 \\
\hline & Rumex pulcher & RUMPU & & $\mathrm{x}$ & & & & 2.4 \\
\hline \multirow[t]{8}{*}{2} & Bromus diandrus & BRODI & & $\mathrm{x}$ & & & & 2.5 \\
\hline & Hordeum murinum & HORLE & & $\mathrm{x}$ & & & & 2.5 \\
\hline & Crepis vesicaria & CVPVT & & $\mathrm{x}$ & & & & 2.7 \\
\hline & Medicago polymorpha & MEDPO & & $\mathrm{x}$ & & & & 2.7 \\
\hline & Andryala integrifolia & ADYIN & & $\mathrm{x}$ & & & & 2.8 \\
\hline & Anagallis arvensis & ANGAR & & & $\mathrm{x}$ & & & 3.0 \\
\hline & Phalaris minor & PHAMI & & & $\mathrm{x}$ & & & 3.0 \\
\hline & Phalaria coerulescens & PHACO & & & $\mathrm{x}$ & & & 3.1 \\
\hline \multirow[t]{3}{*}{3} & Sonchus oleraceus & SONOL & & & $\mathrm{x}$ & & & 3.6 \\
\hline & Scolymus maculatus & SCYMA & & & $\mathrm{x}$ & & & 3.7 \\
\hline & Foeniculum vulgare & FOEVU & & & $\mathrm{x}$ & & & 3.8 \\
\hline
\end{tabular}

Classification of extractable phosphorus $\left(\mathrm{mg} \mathrm{kg}^{-1}\right)$ : (1) $\leq 25$ (very low), (2) 26-50 (low), (3) 51-100 (average), (4) 101 - 200 (high), (5) > 200 (very high); x: barycenter values. 
This work shows that, in the initial phase of implementation of new irrigation areas in Alqueva, there was a slight increase in floristic diversity, which resulted, on the one hand, from the greater diversity of crops, and on the other hand, from the occurrence of some land abandonment in some areas covered by the project. In view of the results obtained and to at least maintain the existing floristic diversity, it is deemed advisable to continue with crop diversification policies in the region and that the weed control strategy be made according to the principles of integrated protection, particularly as regards to the adoption of damage levels which consists, briefly, in the principle of applying herbicides when necessary and with good environmental characteristics. In the case of perennial crops, particularly olive trees, whose regional expression has increased in recent years, the adoption of spontaneous inter-rows vegetation is an important step for the preservation of many floristic values. In turn, knowledge of the environmental preferences of the spontaneous species is important in the choice of the crops to implement, since, when the bioecology of the spontaneous ones and the crops is similar, the weed control becomes more complex and difficult, with higher economic and environmental costs. Thus, the sustainability of the different agroecosystems in the region involves the adoption of a diversified, integrated and coherent set of measures to promote the coexistence of diverse spontaneous flora combined wit crops that are economically viable.

\section{ACKNOWLEDGMENT}

To Professor Doctor Pedro Luís da Costa Aguiar Alves, of Universidade Estadual Paulista, campus Jaboticabal, SP, for the suggestions to the manuscript.

\section{LITERATURE CITED}

ALMEIDA, L. A.; BALBINO, L. R. Determinação de fósforo e potássio assimiláveis em alguns solos do país. Anais ISA, v. 23, n. 1, p. 19-42, 1960.

ARMENGOT, L. et al. Landscape and land-use effects on weed flora in Mediterranean cereal fields. Agric. Ecosyst.

Environ., v. 142, n. 3-4, p. 311-317, 2011.
ATLAS DO AMBIENTE DIGITAL. Descrição: CARTA

III.1 - 2011. Carta de Solos (de acordo com FAO - Carta de Solos da Europa); Escala do original 1:1.000.000; data de execução: 1971. Disponível gratuitamente em: <http:// sniamb.apambiente.pt/webatlas/index.html>. Acesso em: 14 out. 2011.

BORGER, C. P. D. et al. Linking field and farmer surveys to determine the most important changes to weed incidence.

Weed Res., v. 52, n. 6, p. 564-574, 2012.

CALHA, I. M.; SOUSA, E.; GONZÁLEZ-ANDÚJAR, J. L. Infestation maps and spatial stability of main weed species in maize culture. Planta Daninha, v. 32, n. 2, p. 275-282, 2014a.

CHANCELLOR, R. J.; FROUD-WILLIAMS, R. J. A second survey of cereal weeds in central southern England.

Weed Res., v. 24, n. 1, p. 29-36, 1984.

CIRUJEDA, A.; AIBAR, J.; ZARAGOZA, C. Remarkable changes of weed species in Spanish cereal fields from 1976 to 2007. Agron. Sustain. Develop., v. 31, n. 4, p. 675-688, 2011.

DAMANAKIS, M. Weed species in wheat fields of Greece 1982, 1983 survey. Zizaniology, v. 1, n. 1, p. 85-90, 1983.

DEVINEAU, J. L.; FOURNIER, A. Integrating environmental and sociological approaches to assess the ecology and diversity of herbaceous species in a Sudan-type savanna (Bondoukuy, western Burkina Faso). Flora, v. 202, n. 5, p. 350-370, 2007.

DEZZEO, N. et al. Changes in soil properties and vegetation characteristics along a forest-savanna gradient in southern Venezuela. For. Ecol. Manage., v. 200, n. 1-3, p. 183-193, 2004.

FARIÑAS, M. R.; LÁZARO, N.; MONASTERIO, M. Ecología comparada de Hypericum laricifolium Juss. y de $H$. juniperinum Kunth en el valle fluvioglacial del Páramo de Mucubají. Mérida, Venezuela. Ecotrópicos, v. 21, n. 2, p. 75-88, 2008.

FRIED, G.; KAZAKOU, E.; GABA, S. Trajectories of weed communities explained by traits associated with species' response to management practices. Agric. Ecosyst. Environ., v. 158, n. 8, p. 147-155, 2012.

FRIED, G.; NORTON, L. R.; REBOUD, X. Environmental and management factors determining weed species composition and diversity in France. Agric. Ecosyst.

Environ., v. 128, n. 1-2, p. 68-76, 2008.

GOMES, M. P.; SILVA, A. A. Um novo diagrama triangular para a classificação básica da textura do solo. Garcia Orta, v. 10, p. 171-179, 1962.

Planta Daninha, Viçosa-MG, v. 33, n. 3, p. 387-394, 2015 
HIDALGO, B.; SAAVAEDRA, M.; GARCÍA-TORRES, L. Weed flora of dryland crops in the Córdoba region (Spain). Weed Res., v. 30, n. 5, p. 309-318, 1990.

HOLZNER, W.; IMMONEN, R. Europe: an overview. In: HOLZERNER, W.; NUMATA, M., (Ed.). Biology and ecology of weeds. The Hague: W. Junk, 1982. v. 2. p. 203-226. (Geobotany, 2)

HYVÖNEN, T.; HOLOPAINEN, J.; TIAINEN, J. Detecting the spatial component of variation in the weed community at the farm scale with variation partitioning by canonical correspondence analysis. Weed Res., v. 45, n. 1, p. 48-56, 2005.

JOHNSON, D. E.; KENT, R. J. The impact of cropping on weed species composition in rice after fallow across a hydrological gradient gradient in west Africa. Weed Res., v. 42, n. 2, p. 89-99, 2002.

JOSÉ-MARIA, L. et al. Effects of agricultural intensification on plant diversity in Mediterranean dry land cereal fields.

J. Appl. Ecol., v. 47, n. 4, p. 832-840, 2010.

KARAR, R. O.; MOHAMED, B. F.; MARRS, R. H. Factors influencing the weed flora in Gezira Scheme, Sudan.

Weed Res., v. 45, n. 2, p. 121-129, 2005.

MESLI, K.; BOUAZZA, M.; GODRON, M. Ecological characterization of the vegetable groupings of the mounts of Tlemcen and their facies of degradation (West-Algeria).

Environ. Res. J., v. 1/2, n. 5, p. 271-277, 2008.

MONTEIRO, A. et al. Vineyard weed community dynamics in the Dão winegrowing region. Ci. Técnica Vitivin., v. 27, n. 2, p. 73-82, 2012.

RECASENS, J. et al. Grass weeds growing in winter cereals of Catalonia. ITEA Produc. Veg., v. 92, n. 2, p. 116-130, 1996.
SAAVEDRA, M. et al. Influence of environmental factors on the weed flora in crops in the Guadalquivir valley. Weed Res., v. 30, n. 5, p. 363-374, 1990.

SALONEN, J.; HYVONEN, T.; JALLI, H. Weeds in spring cereal fields in Finland - a third survey. Agric. Food Sci. Finland, v. 10, n. 4, p. 347-364, 2001.

SANS, F. X. et al. La intensificación agrícola y la diversidad vegetal en los sistemas cerealistas de secano mediterráneos: implicaciones para la conservación. Ecosistemas, v. 22, n. 1, p. 30-35, 2013.

STOATE, C. et al. Ecological impacts of early 21 years st century agricultural change in Europe - A review. J. Environ. Manage., v. 91, n. 1, p. 22-46, 2009.

STORKEY, J.; WESTBURY, D. B. Mini-review. Managing arable weeds for biodiversity. Pest Manage. Sci., v. 63, n. 6, p. 517-523, 2007.

SUTCLIFFE, O. L.; KAY, Q. O. N. Changes in the arable flora of central southern England since the 1960s. Biol.

Conserv., v. 93, n. 1, p. 1-8, 2000.

VASCONCELOS, T.; MOREIRA, I.; PORTUGAL, J. Flora infestante na cultura do tomate para indústria no Baixo Alentejo. Actas Hortic., v. 3, p. 308-311, 1999a.

VASCONCELOS, T.; TAVARES, M.; GASPAR, N. Aquatic plants in the rice fields of the Tagus valley, Portugal.

Hydrobiología, v. 415, n. 1, p. 59-65, 1999b.

WALTHER, G. et al. Ecological responses to recent climate change. Nature, v. 416, p. 389-395, 2002.

ZAS, R.; ALONSO, M. Understory vegetation as indicators of soil characteristics in northwest Spain. For. Ecol.

Manage., v. 171, n. 1-2, p. 101-111, 2002. 